\title{
Die stil van my verlange na God: Oor Johann Wilhelm Herrmann se verstaan van die ervaring van God 1
}

D P Veldsman

\section{ABSTRACT}

Quenching my thirst for God: On Johann Wilhelm Herrmann's understanding of the experience of God

This article, which is divided into two parts, focusses on the concept of the "experience of God" as understood by the German systematic theologian Wilhelm Herrmann (1846 - 1922) of Marburg in his "Der Verkehr des Christen mit Gott" (1886). The first part of the article explains the historical and theological context of Herrmann's "Der Verkehr..." as well as the theological frontiers overagainst which he responded in his understanding of the experience of God. For Herrmann, this experience can not be justified by means of historical investigation. Neither is this experience a "holding for true" of doctrines nor has it its origin in humans themselves, but is rather a "search-find-experience" of the overwhelming "image of Jesus" in God's revelatory engagement with humanity. If, and only if, we search for the gracious God wholeheartedly, can he himself be found and not one or other doctrine or gift of God. The second part of the article elaborates on this "search-find-experience" by humans of God as understood by Herrmann, and indicates the influence it had on Herrmann's two greatest pupils, namely Karl Barth and Rudolf Bultmann. It is argued that Herrmann's understanding of the experience of God makes up the kernel of their theological vantage points, and in this respect, is critically evaluated.

\section{DEEL I}

\section{INLEIDING}

Die "jong"2, maar uiters populêre begrip "ervaring" met haar semantiese veelsydigheid en diepgang oor verskillende kontekste heen, dwing tot die vraag: Wat word met hierdie begrip bedoel wat in 'n steeds toenemende mate soos verbale paddastoele opspring in die groen gras van onder andere alledaagse omgangstaal, wetenskaplike vaktaal, die filosofie en teologie, tegniese taal (Enkele voorbeelde: Dit was 'n goeie/slegte ervaring; die 
postmoderne ervaring; die ervaring van God; "experiencing the Internet" ens). Nie alleen vra die omvangryke gebruiksinflasie van die begrip "ervaring" dat daarvan ernstig notisie geneem moet word nie, maar ook die al groter wordende klem in verskillende kerklike kringe op "ervaring" is meer as net opvallend.

Versigtigheid en waagmoed met die begrip "ervaring" word egter geëis, en weliswaar beide op eiesoortige wyse as waarskuwing. Enersyds versigtigheid as ons die waarskuwing van Gadamer ernstig neem dat hierdie gewilde gebruikswoord een van die "onduidelikste begrippe" ("unaufgeklärtesten Begriffen") is wat lustig gebruik word asof almal presies verstaan wat daarmee bedoel word, terwyl die begrip inhoudelik nie so maklik vasgepen kan word nie ${ }^{3}$. Andersyds waagmoed as ons die waarskuwing van Ebeling ter harte neem waarin hy aanvoer dat die eietydse "ervaringstekort" ("Erfahrungsdefizit") of "gebrek aan ervaring" ("Erfahrungsmangel") vir die geloofslewe en teologiese nadenke dodelik kan wees ${ }^{4}$. Juis die toenemende gebruik van die begrip (soos reeds bo genoem) en die gelyktydige verwoording van 'n ervaringstekort, skep alreeds ' $n$ interessante vraagstelling, maar ook agterdog.

Afgegrens tot 'n religieus-teologiese konteks en toegespits op 'n spesifieke persoon, naamlik Wilhelm Herrmann wil ek hierdie voorafgaande vraag oor "ervaring" waagmoedig en versigtig opneem en vanuit sy teologie 'n perspektief op "ervaring” gee. Maar waarom spesifiek die duitse teoloog Herrmann van die twintigste eeuwende aan die woord stel oor (geloofs)ervaring? Omdat Herrmann - na my oordeel - sy besondere stempel invloedryk afgedruk het op die westers-teologiese ervaringsbegrip en hierdeur die twintigste eeu (Europese) strominge na hom grondliggend beïnvloed het. Hierop wil ek fokus.

Eerstens wil ek my keuse vir Herrmann motiveer. Tweedens wil ek konsentreer op die wyse waarop hy die begrip inhoudelik - en ingrypend invloedryk - gestempel het in veral sy Der Verkehr des Christens mit Gott. Daaropvolgend wil ek die wyse waarop die ervaringsverstaan van Herrmann - na my oordeel - die teologiese uitgangspunte van sy twee beroemdste studente, Barth en Bultmann beïnvloed het en hiermee saam, ten slotte, die verskuilde problematiek in sy ervaringsbegrip aandui.

\section{MY KEUSE VIR HERRMANN}

Vir min Suid-Afrikaanse teoloë lui die naam Herrmann (1846 - 1922) enigsins 'n teologiese klok. In die Duitse sistematies-teologiese tradisie het Herrmann wel 'n besondere plek gehad en 'n belangrike bydrae gelewer. 
Vanaf 1879 was Herrmann vir 37 jaar professor in Sistematiese Teologie te Marburg, Duitsland. Deurgaans het sy studente met baie lof gepraat van sy begeesterde voorlesings 5 . In die tydperk vanaf 1875 tot 1922 was Herrmann verantwoordelik vir meer as 130 vakkundige bydraes (sy Dogmatik verskyn eers in 1925, drie jaar na sy dood). In Marburg was hy die leermeester van twee van die grootste Duitse teoloë van die twintigste eeu, naamlik Karl Barth en Rudolf Bultmann. Sowel Barth ${ }^{6}$ as Bultmann 7 het met groot lof van Herrmann gepraat ten spyte vain eikeen se onderskeie teologiese kritiek op hom asook die onderskeie teologiese rigtings wat hulle ingeslaan het ${ }^{8}$. Ook die Duitse filosoof Heidegger, tydgenoot van Bultmann en saam dosent in Marburg, skryf met waardering oor Herrmann'. In kontemporêre Duitse sistematies-teologiese werke kom 'n kritiese waardering van verskeie elemente vanuit Herrmann se teologiese bydrae wydverspreid voor ${ }^{10}$. Daarom die vraag: Is daar nie dalk meer aan die teologie van Herrmann as wat in teologiese hoofstrominge in berekening gebring word nie? Kan hy nie net dalk in sekere opsigte help met 'n meer insigtelike beskrywing van dimensies van die Godservaringe nie? Of is juis sy ervaringsbegrip problematies?

Die voorafgaande aanduidinge en vrae is na my oordeel voldoende aanleiding om opnuut na Herrmann se teologiese bydrae te kyk. Daar kom egter dan nog 'n vraag by: Waarom Herrmann se teologiese ontwerp spesifiek vanuit 'n ervaringsperspektief benader? Hierop is - na my oordeel - Herrmann se eie antwoord voldoende. Meermale beskrywe Herrmann"1 self hoe hy sy teologiese taak sien, naamlik as die beskrywing van die innerlike ervaring deur die gelowige van God. Verskeie navorsers bevestig dan ook hierdie taak wat Herrmann vir homself gestel en onderneem het, naamlik die vraag na die ontstaan van die geloofservaring ${ }^{12}$. Op oortuigende wyse is elders reeds aangetoon dat Herrmann die eerste teoloog was wat die begrip "ervaring" in samehang met die begrip "lewe" vir die teologie bruikbaar gemaak het ${ }^{13}$. Voeg hierby dan nog die woorde van Fischer-Appelt ${ }^{14}$ oor Herrmann, naamlik: "In die voorlesingsaal van Herrmann het studente tot bekering gekom", is daar voldoende grond na my mening reeds aangedui - in aansluiting by die voorafgaande opmerkinge - om Herrmann se teologiese ontwerp met groter noukeurigheid van nader te ondersoek, en dan spesifiek vanuit 'n ervaringsperspektief. Meer nog: Vir sistematies-teologiese denke en voorlesings wat dikwels (meestal?) deur studente as oninteressante, abstrakte formuleringe ervaar word, sê dit na my oordeel baie as daar van Barth en Bultmann se leermeester gesê word dat studente tot bekering gekom het. Boonop het die studentegetalle binne die eerste sewe jaar van Herrmann se aanvaarding van die professoraat te Marburg, van 60 tot 176 gegroei $^{15}$. 
Op die grafsteen van Herrmann staan die woorde van Jeremia 29:13 geskrywe:

"Julle sal vra na my wil en julle sal dan my wil ken as julle met julle hele hart daarna vra" 16 .

Treffend verwoord hierdie Ou-Testamentiese teksvers in terugblik op die lewe en teologiese nadenke van Herrmann die mees uitstaande kenmerk daarvan, naamlik die ervaring van God as 'n "passievolle soek-vindervaring" wat in die innerlike lewe van die gelowige navoltrek word in die ontmoetingsgebeure van die tegemoettredende God in Jesus Christus. Anders gesê: Die mens gryp na God, omdat die mens in die greep van God is. Self verwoord Herrmann ${ }^{17}$ by geleentheid op kenmer-kende wyse sy verstaan van hierdie ontmoetingsgebeure:

"God laat Homself slegs vind in daardie moment waarin ons Hom met ons hele hart soek"18.

Vir Herrmann was die "vind van God" 19 as "daad van God" 20 die hoogste goed vir die mens. Dit is juis hierdie soek en vind van God as hoogste goed wat Herrmann op 'n heel besondere wyse verstaan en geformuleer het. Opvallend anders as sy teologiese tydgenote verwoord Herrmann ${ }^{21}$ die religieuse inhoud van die hoogste goed vir die mens:

"Die verlange van ons siel na ware lewe word nie daardeur gestil dat ons leerstellinge oor God moet formuleer en moet verdedig (letterlik: "aanhang") nie, maar word alleen gestil deur God self te vind". En:

"Deur te glo (letterlik: in religie -DPV) soek die mens nie bloot na die gawes van God nie, maar na God self aangesien dit wat God gee sonder om Homself te gee, die mens nie kan troos nie"22.

Hoe vind ons hierdie God wat Homself aan ons wil gee en wat op hierdie wyse alleen die verlange van ons siel kan stil? Anders gevra: Hoe openbaar God Homself kenbaar aan ons? Bewyse kan dit nie regkry om ons van God se openbaring te oortuig nie ${ }^{23}$. Herrmann ${ }^{24}$ se antwoord hierop is kort en kragtig:

"Ons kan God alleen maar ken deurdat Hy Homself aan ons openbaar in sy bemoeienis (letterlik: 'werkinge') met ons ('indem er auf uns wirkt')".

In aansluiting by Luther en die Reformasie, worstel Herrmann ${ }^{25}$ dwarsdeur sy teologiese loopbaan met die allesbepalende vraag: "Hoe kan ek seker wees dat God 'n God van genade is?". Anders gevra: Sal ek God kan vind 
as ek met oorgawe na God soek? Sal God my tegemoettree? Hierdie vraag kan - aldus Herrmann - nou met sekerheid beantwoord word. Vol oortuiging skryf die sestigjarige Herrmann ${ }^{26}$ dan:

"Wie nou wil sien, wie nou na God soek en die pad wat na Christus heenlei, wil vind, kan die pad vind, ja selfs in 'n wêreld wat deur die wetenskap verander is".

Wat is hierdie pad wat vir Herrmann heenlei na die vind van God, na 'n Godservaring? En: wat is dit terselfdertyd ook nie?

Inhoudelik spel Herrmann sy verstaan van die ervaring van God as "soek-vind-ervaring" wat voltrek word in die innerlike lewe van die gelowige, uit in veral sy Der Verkehr des Christen mit Gott (1903). Hieropvolgend word hierna gekyk vanuit die historiese konteks van sy lewe en van sy boek.

\section{EKSKURS: Der Verkehr des Christen mit Gott}

Hierdie boek van Herrmann verskyn die eerste keer in 1886. In onderskeidelik 1892 en 1896 verskyn twee verdere oorgewerkte en uitgebreide uitgawes. In 1903 verskyn die vierde veranderde uitgawe, terwyl die vyfde en sesde uitgawes in 1908 verskyn. In laasgenoemde twee uitgawes is slegs geringe veranderinge aangebring. ' $n$ Laaste onveranderde sewende uitgawe verskyn in 1921. In hierdie artikel word van die 1903 uitgawe gebruik gemaak. Dit is verder ook interessant om op die teologiese ontvangs en reaksie van hierdie boek en die verdere uitgawes te let. Op elkeen van hierdie uitgawes is deur ander teoloë by wyse van resensies of kort kommentaar reageer. Op die eerste uitgawe het nie minder as sestien kort artikels verskyn nie, terwyl Herrmann self in ses kort artikels hierop reageer het. Ses kort artikels verskyn as reaksies op die tweede uitgawe, terwyl Herrmann in een artikel hierop antwoord. Vier en tien artikels verskyn onderskeidelik op die derde en vierde uitgawe. Op die vyfde en sesde uitgawe van 1908 verskyn 10 reaksies. In Fischer-Appelt ${ }^{27}$ verskyn 'n volledige bibliografie hiervan, asook 'n bibliografie van sekondêre literatuur oor Herrmann in die tydperk 1875-1964. Weinhardt ${ }^{28}$ bespreek baie insigtelik en breedvoerig in sy ongepubliseerde proefskrif die veranderinge wat Herrmann oor die jare aangebring het aan sy Der Verkehr ${ }^{29}$.

\section{TYDPERK VAN INTENS-TEOLOGIESE GESKARREL}

Intellektuele en politieke onrus stempel die duitse leefwêreld van die laat $19 \mathrm{de}^{\mathrm{eeu}}{ }^{30}$. Op intellektuele gebied is die onrus vanuit verskeie oorde 
teweeggebring: Die toenemende intensiteit van die jong Hegeliane (Feuerbach, Kierkegaard en Marx) in hulle rebellie teenoor hulle leermeester. Die ingrypende konsekwensies van Darwin se ewolusieleer; Nietzsche se formulering van die aanspraak van die mondige mens asook die uitbreidende invloedsfeer van die naturwetenskap wat 'n nog groter bedreiging geword het vir menslike vryheid. Op politieke gebied is die onrus deur die stryd van die feodale stand om beheer te behou, opkomende nasionalisme en die liberale eis tot gelykheid, teweeggebring.

Binne hierdie konteks formuleer Herrmann in die laat sewentigerjare van die negentiende eeu sy verstaan van die wese van religie (geloof) in verhouding tot sedelikheid en die wetenskap. Hierdie verhouding word as 'n struktureel-korrelatiewe verknoping van sedelikheid en religie gedui, naamlik die sedelike selfbewussyn as die algemeengeldige verstaanshorison van die religie, en sedelike selfbesinning as die algemeengeldige ontstaansvoorwaarde ${ }^{31}$. In kritiese aansluiting by sy leermeester Ritschl, sy Marburgse filosofie kollegas Cohen en Natorp, en veral Kant en Schleiermacher ${ }^{32}$, rig Herrmann hom teologies teen twee fronte, naamlik die kerklik-peïtistiese ortodoksie en die kerklik-teologiese liberalisme. Eersgenoemde front het as kern die oortuiging gehad dat geloofsformuleringe tydloos-geldend vir-waar-gehou moet word, dit wil sê om Christen te wees het eenvoudig beteken dat jy met hierdie geloofsformuleringe moes saamstem. Hiermee saam kon die geloofsformuleringe nie bevraagteken word nie, aangesien hierdie waarhede direk en kantklaar aan die mens deur God geopenbaar is. Vir Herrmann ${ }^{33}$ het hierdie geloofsverstaan 'n "slawe-ketting" vir gelowiges geword, en vir hulle wat nog na geloof soek, het dit van geloof 'n ondeurdringbare "kruik" (Fessel) gemaak. Laasgenoemde front, naamlik die kerklik-teologiese liberalisme, het as kern die oortuiging gehad dat geloof haar oorsprong vind in die mens self, naamlik in die feit dat die mens op sigself ' $n$ religieuse wese is. Dit het Herrmann ontken aangesien geloof vir hom alleen maar 'n gawe van God kon wees. Teenoor hierdie twee fronte stel Herrmann ${ }^{34}$ dat geloof nie beteken om nie-insigtelike geloofsformuleringe vir waar te hou nie. Geloof spruit nie voort uit die feit dat die mens insigself 'n religieuse wese is nie. In Der Verkehr des Christen mit Gott verwoord Herrmann sy verstaan van die godservaring ten aansien van hierdie twee fronte. Voordat vervolgens hieraan aandag gegee word, moet hierdie boek van Herrmann binne die historiese konteks van sy eie teologiese loopbaan geplaas word. 


\subsection{Hermann en sy Der Verkehr}

In die teologiese loopbaan van Herrmann wat strek vanaf 1876 tot 1922 , kan ten minste drie fases aangedui word ${ }^{35}$. Hierdie fases moet verstaan word as vlakke van tematiese toespitsing en verdieping binne die raamwerk wat deurgaans in die denke van Herrmann sentraal gebly het ${ }^{36}$. Hierdie raamwerk was sy verstaan van die religie in relasie tot die wetenskap en sedelikheid in beantwoording van die grondvraag na die sekerheid van die geloof. Die drie fases kan losweg aan drie tydperke gekoppel word aan die hand van spesifieke publikasies van Herrmann. Eerstens, die tydperk 18761884 waarin die vraag na die metafisika in die teologie in verhouding tot die wetenskap en sedelikheid voorop staan. Tweedens, die tydperk vanaf 1884-1900 waarin die vraag na die historiese dimensies van die geloof uiteengesit word, in besonder die verhouding van geloof tot geskiedenis. Derdens, die tydperk 1900-1922 waarin gefokus word op die vraag na lewe as teologiese probleem.

Herrmann se Der Verkehr stempel inhoudelik bogenoemde tweede fase. Alhoewel die eerste uitgawe van hierdie boek reeds in 1886 verskyn, het hy in 1892 hierdie boek volledig oorgewerk. Met die derde en vierde uitgawes van 1896 en 1903 onderskeidelik, het hy nog verdere veranderinge aangebring. Die oorwerk van die eerste uitgawe en die veranderinge wat deur Herrmann hierin aangebring is (veral $\mathrm{m} \mathrm{b} t$ die herdefiniëring van die begrip Glaubensgedanken), bevestig die indeling van 'n onderskeie tweede fase waarin die tematiese fokuspunt verskuif het na die vraag na die historiese dimensies van die geloof, dit is, die vraag na die ervaring van god(sopenbaring) in Jesus Christus ${ }^{37}$. Veral twee vrae ${ }^{38}$ karakteriseer hierdie fase, naamlik: Op watter wyse kan die geskiedenis grond van die geloof wees (die sg Lessing-vraag), en: Wat is die relasie van die inhoud van die geloof tot die historiese oorsprong van die geloof?

\subsection{Die ervaring van God}

Teenoor twee besware rig Herrmann ${ }^{39}$ sy uitgangspunt met betrekking tot die verstaan van die Godservaring. Eerstens is daar diegene wat sê dat dit nie moontlik is om die persoon van Jesus op so 'n wyse te ervaar dat Hy aan ons geloofsvertroue op God die rus en die krag van die oorwinning kan gee nie. Tweedens is daar diegene wat sê dat dit nie die ervaring van die persoon van Jesus is wat ons help nie, maar dat die reddende mag van die evangelie lê in dit wat van Jesus gesê word (dit wil sê die dinge wat van Hom vertel word). Vir Herrmann is beide hierdie standpunte onaanvaar- 
baar aangesien beide - alhoewel elkeen op afsonderlike wyse - die evangelie hierdeur as "wet" (Lehrgesetz) misverstaan. Of die evangelie word as leerstellinge (geloofsformuleringe) verstaan wat vir-waar-gehou moet word ten einde as Christen gereken te word, of die evangelie word verstaan as blote aanleiding tot eie opvattinge daaroor, dit wil sê geloof het haar oorsprong in die mens. Beide hierdie benaderinge (oortuiginge), in stede daarvan om die weg na God aan te dui, versper juis hierdie weg nie alleen vir hulle wat hierdie weg reeds ingeslaan het nie, maar ook vir ander wat nog na 'n weg soek. Dit versper hierdie weg juis omdat dit op 'n onvanpaste (lett: "sinnelose") wyse ${ }^{40}$ mense met die evangelie konfronteer. Ten aansien van hierdie benaderinge stel Herrmann dié kritiese vrae:

Maak dit van ons Christene wat bloot 'n aantal leerstellinge (bv Jesus as seun van God; die maagdelike geboorte; die verskillende wondere; opstanding uit die dood; hemelvaart) verdedig? ${ }^{41}$. Verander dit ons, verander dit ons lewens; maak dit van ons geloof 'n lewendige geloof? Nee, want juis die "hart van die mens wat God wil hê, is nie deel daarvan nie" 42 . Uit 'n etiese oogpunt is die blote formulering en/of ondersteuning van tydloos-geldende leerstellinge vir Herrmann nie moontlik nie. Boonop is die benadering waarvolgens eie opvattinge hier en nou geformuleer word oor wat die evangelie dan sou beteken, net maar 'n gemaklike plaasvervanger vir dit wat werklik nodig is. Wat is dit wat werklik nodig is volgens Herrmann ten einde hierdie onaanvaarbare standpunte die hoof te bied?

Dit is nodig om te besef dat die grond van geloof alleen dit kan wees wat in ons as die innerlike gebeure van volkome vertroue (inneren Vorgang reinen Vertrauens) voltrek word. Alleen die verwoording van die eie innerlike ervaring van God - wat die enigste gemeenskaplikheid is wat gelowiges deel - kan die vertrekpunt en inhoud wees van gelowige beskrywinge en nadenke oor die ervaring van God. Anders gesê: Vir Herrmann ${ }^{43}$ is die grond en die inhoud van die geloof as ervaring van God een en dieselfde gebeurtenis. Hoe Herrmann by hierdie oortuiging ten opsigte van die Godservaring uitkom en dị motiveer, moet ons vervolgens op let.

\subsubsection{Die "Evangeliese leerstellinge" as eie oortuiging}

"In die evangeliese kerk (dit is, in onderskeid met die Roomse kerk DPV)... gaan dit daarom om die Bybelse leerstellinge as jou eie oortuiginge te bely" 44 .

Vir Herrmann lê die besondere van die evangeliese geloof juis daarin dat ons deur die Bybel met ons eie lewens persoonlik gekonfronteer 
word aangesien God se verlossende openbaring ons juis hierin as werklikheid "voor ons eie oë" tegemoettree. Twee vrae spruit hieruit voort: Waar pas leerstellighede dan in? En: Wat is hierdie verlossende openbaring van God wat ons voor ons eie oë tegemoettree? Eerstens, alhoewel die formulering van leerstellighede immer 'n versugting van die kerk sal wees en daarmee saam, gepoog sal word om gelowiges hierin te verenig, sal dit altyd 'n onafgehandelde taak wees en voortdurendveelkleurig (unermessliche Mannigfaltigkeit) tot uitdrukking kom. As mensewerk is dit nie moontlikheid om ooit tot eenvormige (Gleichformigkeit) geloofsformuleringe te kom oor Gods tegemoettredende werklikheid in ons lewens nie. Die poginge daartoe maak van die evangelie opnuut weer 'n wet en strook boonop nie met die persoonlike, lewendige aard van die christelike geloof nie ${ }^{45}$. Die enigste eenheid lê opgesluit in die eenheid van die openbaring, dit is, om op dieselfde wyse Gods openbaring aan ons opnuut te ervaar. Die meeste wat van leerstellighede gesê kan word, is dat ons daardeur aan die christelike geloof bekend gestel word. Dit waarborg op geen manier dat so 'n persoon tot geloof sal kom nie. Of beter gesê: Dat so 'n persoon God sal ervaar nie. Herrmannn ${ }^{46}$ stel dit soos volg:

"Deur die somtotaal van christelike leerstellighede te ken, ken ons alleen gemeenskap met God as taak, maar het geen waarborg dat ons God enigsins sal ervaar nie".

Tweedens, God se verlossende openbaring is niks minder en anders as die werklikheid - wat ons innerlike lewe verander - van die persoonlike lewe van Jesus nie. Hoe tree dit ons konkreet tegemoet? In die aanspraak wat die eenvoud van die sedelike (sittliche) gebod of sedewet op ons maak. Vir Herrmann is die sedelike gebod niks anders as opregtheid (Wahrhaftigkeit) en liefde nie ${ }^{47}$. Anders gesê: Die wêreld van die geloof is niks anders as die tuiste van die sedelik-bewusgeworde mens nie ${ }^{48}$. Religie en sedelikheid word struktureel-korrelatief verknoop. Wat maak dit spesifiek christelik? Dit is alleen waarlik christelik indien dit ervaar word as gemeenskap (Verkehr) van die siel met die lewende God wat deur Christus moontlik (lett: "bemiddel") gemaak is. Hoe moet hierdie gemeenskap verstaan word? Is dit 'n mistieke ervaring?

Vir Herrmann is daar geen onderskeid tussen diegene wat poog om van die evangelie 'n wet van leerstellighede te maak en diegene wat anvoer dat die mistiek die ware vergestalting is van die christelike geloof nie $^{49}$. Ook die aanspraak van die mistiek dat gevoel die Godservaring sou kon begrond, is vir Herrmann nie houdbaar nie, aangesien dit niks nuuts en niks meer tot die mens toevoeg of meebring nie. Beide benaderingswyses 
(naamlik evangelie as wet en die mistiek) verpas of verwaarloos die allesbepalende betekenis van Gods openbaring in die geskiedenis.

\subsubsection{Gods openbaring}

"Wat ons as Christene werklik met mekaar en met die geloofsgetuies van die Nuwe Testament verbind, is nie om dieselfde weer maar oor te sê as wat hulle gesê het nie (Gleichheit der Gedanke), maar om op dieselfde wyse as hulle te dink (Gleichartigkeit des Denkens)" 50.

In sy verstaan van Gods openbaring rig Herrmann hom pertinent teenoor die opvatting van die ortodokse protestantisme, te wete, dat hulle teologiese "hooftaak" (Hauptaufgabe) daarin geleë was om Gods woord, soos oorgelewer deur die getuies van die Christendom, in 'n logiessamehangende geheel te orden. Gods openbaring was dus hiervolgens die afgeslote en geskrewe Bybel soos dit aan ons oorgelewer is. Terselfdertyd rig Herrmann ${ }^{51}$ hom teen die onaanvaarbare Rooms-Katolieke praxis (bv van selfverloëning deur die Jesuïte) waarin nie vir die innerlike lewe van 'n Christen wat dors na waarheid en werklikheid, gesorg word nie. Herrmann verstaan God se openbaring nie soos die ortodokse protestantisme nie. Ook verwag hy "meer" van die openbaring van God as die rooms-katolieke oortuiging. Om meer te kan verwag van God se openbaring, wil hy "verder" teruggryp. Hy wil teruggryp na dit wat voor hierdie geskrewe teks gebeur het en wel na die ontstaan van hierdie geloofsoortuiginge in die ervaring van God. In Herrmann"52 se eie woorde: "Ons stel dus Gods

openbaring nie voor as iets wat aan ons oorgelewer is nie, maar as iets wat hier en nou groei, as geloofsoortuiginge".

Waarom wil Herrmann hierna teruggryp? Hoe word hierdie onderskeid van "dieselfde dink" en nie "dieselfde net weer oorsê" verstaan? Na my oordeel is daar veral twee redes te vinde by Herrmann hoekom hy hierna teruggryp. Eerstens, geloofsoortuiginge is vir Herrmann 'n vrug van ons verlossing en kan dus nie die grond van ons geloof wees nie. Duidelik stel hy:

"Dieselfde belydenisse (Gedanken) aangaande Christus wat by sommige 'n teken van hulle verlossing kan wees, sal vir ons tot nadeel strek (verderblich) indien ons ons sou laat oortuig dat ons hierdie belydenisse sou moes aanvaar ten einde verlos te word" 53 . Tweedens, Herrmann wil 'n antwoord gee op die onopgeloste vraag: Hoe kan (objektiewe) geloofsoortuiginge as my eie (subjektiewe) oortuiging bely word? Vir Herrmann is dit van allesbepalende belang, aangesien hy aanvoer dat die oortuiginge (Gedanken) van ander wat verlos is, my nie 
kan verlos nie. Kortliks, God het nie van ons geloofsparasiete gemaak nie. Die vraag vir Herrmann is nie: Hoe die onverloste mens die oortuiginge van verloste mense tot sy/haar eie mak nie? Die vraag is wel: Wat is die samehang van Godservaringe en objektiewe werklikheid, dit wil sê diegene wat bely dat hulle God gevind het, en my werklikheid waarin ek na God soek en Hom vind?

Hierdie samehang kan vir Herrmann alleen beantwoord word indien aangetoon kan word (a) watter mag kan geloof laat ontstaan en begrond, en (b) hoe geloofsoortuiginge as my eie oortuiginge bely kan word? In die beantwoording van hierdie vraag, wil Herrmann hom laat lei deur Luther en spesifiek deur Luther se getuienis en worsteling, en nie deur sy teologie $n^{5} e^{54}$.

As uitgangspunt onderskei Herrmann tussen "leerstelling" en "werklike gebeure" (Tatsache), dit wil sê die handhawing van 'n sekere oortuiging en/of voorstelling van iets (fides quae creditur), in onderskeid met 'n werklike gebeure. Dat God bestaan en vir ons daar is, kan geen leerstelling in ons met volle sekerheid bewerk nie. Ons kan dit hoor en virwaar-hou, maar sekerheid kan dit nie bewerkstellig nie. Alleen laasgenoemde, naamlik 'n werklike gebeure as daad van God kan in ons hierdie vertroue meebring. In Herrmann ${ }^{55}$ se eie woorde:

"Ons sekerheid oor God kan aan die hand van baie ander ervaringe ontstaan (lett: 'ontbrand' - DPV), maar die enigste blywende grond waarop dit in die laaste instansie vas kan staan, is die feit (Faktum) dat ons in die geskiedenis, waaraan ons self deel (lett: 'behoort' DPV) het, die mens Jesus teëkom as onbetwyfelbare werklikheid (lett: 'as iets wat sonder twyfel 'n werklikheid is')".

Hoe kom ons hierdie onbetwyfelbare werklikheid van die mens Jesus teë? Ander gelowige mense kan deur hulle godsdienstige lewens en ywer alleen maar "brokstukke" wees van die openbaring van God, alhoewel hulle hierdeur ten meeste die openbaring van God deur hulle lewens vir ander mense kan verdiep en inhoud gee (lett: 'voleindig' - DPV). Waarom net brokstukke? Omdat, volgens Herrmann ons dit waarvoor ons ons hele lewe op die spel plaas, nie sondermeer by ander mense kan kry nie. Eers in die aanskouing van die persoon van Jesus self word ons oë geopen vir die onsigbare. Dat Jesus die Christus is, begrond ons verhouding (Verkehr; Gemeinschaft) met God en is nie die grond vir die formuleer van leestellighede oor Jesus of God nie. Selfs nie eers die getuienis van oudIsrael oor hulle ervaringe met God kan die grond wees vir ons ervaring van God nie. Waarom nie? Duidelik stel Herrmann ${ }^{56}$ :

"Op geen manier kan ons ons volledig indink in die godsdienstige lewe van 'n vroom Israeliet nie". 
En:

"Aangesien ons ons nie as jood kan indink nie (lett: 'soos 'n jood kan voel nie' - DPV), is die openbaring waaraan Israel deelgehad het, vir ons behoeftes nie voldoende nie" 57 .

Wat is hierdie behoefte? In besonder geld vir Herrmann die verdieping van die sedelike bewussyn en dié daaruit voortspruitende sedelike nood as eietydse behoefte en uitdaging vir die verhouding met God. Dit beteken: God openbaar Homself as die mag ten midde van ons sedelike stryd, juis as die werklike mag waaraan ons ons innerlik kan onderwerp ten einde erns te maak met die konkrete werklikheid waarin ons ons bevind ${ }^{58}$. Dit is juis die wêreld van die geskiedenis as konkrete werklikheid wat die inhoud van ons persoonlike lewens moet word. In hierdie konkrete werklikheid is daar vir die mens geen belangriker gebeure as die persoon van Jesus Christus nie. Om dit te ontken, is om jouself die beste moontlike inhoud vir jou lewe te ontsê.

Maar wat kan ons van hierdie Jesus sê? Sê ons nie maar net van Hom wat die geskiedenis vir ons van Hom vertel nie? Kan ons dan nie op die wetenskap van histories-kritiese ondersoek staatmaak om aan ons 'n duidelike boodskap en beeld van Jesus oor te dra nie? Vir Herrmann kan hierdie ondersoek niks meer as "waarskynlikhede" opdiep nie. Ook help hierdie ondersoek ons nie omdat dit uitgaan van die valse oortuiging dat die betroubaarheid van die oorlewering die eintlike grond van ons geloof is. Voeg hierby nog die psigologiese toedrag van sake dat mense gebeure/verhale vanuit die verlede "omvorm" om by hulle eietydse verstaanshorison en omstandighede te pas, dan blyk verder die onvanpastheid van "historiese" betroubaarheid as kriterium. Al wat dan nog oorbly, is twyfel aangesien geen geloof kan bly staan wat maar bloot op waarskynlikheid begrond is nie ${ }^{59}$. So 'n geloof sal uiteindelik geen rus vind nie aangesien die historiese ondersoek alleen maar 'n probleem van Jesus Christus maak en nie 'n werklikheid nie. Dit is 'n fatale flater (verhängnisvoller Irrtum) om enigsins te probeer om die grond van die geloof deur historiese ondersoek te wil bevestig. Die grond van die geloof moet vasstaan. Hierteenoor verander die resultate van historiese ondersoek voortdurend. Dit beteken egter nie dat historiese ondersoek van die Nuwe Testament geheel en al sonder waarde is nie. Enersyds - negatief - toon dit duidelik aan ons hoe onvanpas dit is om die Nuwe Testamentiese geskrifte as dokumente te wil gebruik wat vir ons as historiese bewyse moet dien vir wat Jesus Christus vir die gelowige sou beteken. Veral in die ontmaskering van valse geloofstutte en die voortdurende taak om opnuut te verstaan wat Jesus hier en nou beteken, lê die grootste waarde van historiese ondersoek. 
Andersyds - positief - word ons juis deur historiese ondersoek gehelp om te groei in die erkenning van die onuitputlikheid van die innerlike lewe van Jesus.

$\mathrm{Na}$ die wyse waarop Herrmann die onuitputlikheid van die innerlike lewe van Jesus en Gods openbaring verstaan, word in die tweede gedeelte van hierdie artikel gekyk sowel as die aansluiting van Barth en Bultmann hierby.

\section{NOTAS:}

1 Erkenning word hiermee met dank verleen aan die volgende instansies, naamlik die Deutscher Akademischer Austauschdienst (Duitsland), die SWO, Raad vir Geesteswetenskaplike Navorsing en die Fakulteit Teologie (Afd B) vir finansiële ondersteuning van my navorsingsbesoek (Nov 1994 - Jan 1995) aan die Eberhard-Karls Universität, Tübingen, Duitsland waartydens hierdie artikel geskrywe is. My dank veral ook aan prof Eberhard Jüngel vir sy kritiese gespreksbydrae tot hierdie artikel. Menings hierin uitgespreek, is my eie. In waardering dra ek hierdie artikel op aan prof Johan Heyns, my leermeester en afgetrede professor in Dogmatiek en Christelike Etiek (Afd B), Universiteit van Pretoria, wat gedurende die skryf van hierdie artikel in Tübingen, koelbloedig in sy huis in Pretoria vermoor is.

2 Oor die "jeugdigheid" van die begrip "ervaring”, sien Wayne Proudfoot, Religious experience, Berkeley 1985.

3. Hans-Georg Gadamer, Wahrheit und Methode: Grundzüge einer philosophische Hermeneutik, Tübingen 1972, 329.

4 Gerhard Ebeling, Wort und Glaube (Band III), Tübingen 1975, 3.

5 Hendrikus Berkhof, 200 Jahre Theologie. Ein Reisebericht, Neukirchen-Vluyn $1985,148$.

6. Karl Barth, Die dogmatische Prizipienlehre bei Wilhelm Herrmann, in: Die Theologie und die Kirche (Band II), München 1928, 240ev; Sien ook Theodor Mahlmann, Herrmann, Wilhelm, in: TRE, Band XV (1986), 171

7 Rudolf Bultmann, Zur Frage der Christologie, (1927) in: Rudolf Bultmann, Glauben und Verstehen, Band I, Tübingen 1961, 101.

8 Daniël Veldsman, Etisering - personalisering - eksistensialisering van die geloofsbegrip. Ongepubliseerde DD-proefskrif, Universiteit van Pretoria 1989, $116 \mathrm{ev}$.

9 Veldsman, $a w, 132$. 
10 Vergelyk onder andere Brecht, Volker, "Das Sittliche als Grundlage der Theologie Wilhelm Herrmanns", Neue Zeitschrift für Systematische Theologie und Religionsphilosophie 34/1 (1992) 47 - 68; Gerhard Ebeling, Wort Gottes und Tradition, Göttingen 1964, 79; Gerhard Ebeling, Wort und Glaube, Tübingen 1967, 9; Helmut Gollwitzer, Die Existenz Gottes im Bekenntnis des Glaubens, München 1988, 9ev; Eberhard Jüngel, "Anrufung Gottes als Grundethos christlichen Handelns”, in: Anspruch der Wirklichkeit und christlicher Glaube, Düsseldorf 1980; Friedrich Kantzenbach, Programme der Theologie, München 1984, 127ev; Jürgen Moltmann, Der Weg Jesu Christi: Christologie in messianischen Dimensionen, München 1989, 248; Paul Tillich, Systematische Theologie, Band I/II, Berlyn 1987, 135ev; Wolfhart Pannenberg, Grundzüge der Christologie, Gütersloh 1972, 17ev; Wolfhart Pannenberg, Systematische Theologie, Band III, Göttingen 1993, 172ev.

11 Wilhelm Herrmann, Der Verkehr des Christen mit Gott. In Anschluss an Luther dargestellt, Cotta 1903, 11; 13; 36-37; veral 92.

12 Vergelyk onder andere F Kattenbusch, Die deutsche evangelische Theologie seit Schleiermacher, Giessen 1924, 64; Peter Fischer-Appelt, "Zum Verständnis des Glaubens", in: Hans-Georg Geyer (hrsg), Freispruch und Freiheit, München 1973, 69; Helmut Thielicke, Glauben und Denken in der Neuzeit, Tübingen $1983,375$.

13 Theodor Mahlmann, "Das Axiom des Erlebnisses bei Wilhelm Herrmann", Neue Zeitschrift für Systematische Theologie 4 (1962), $13 \mathrm{ev.}$

14 Peter Fischer-Appelt, “Wilhelm Herrmann", in: Martin Greschat (hrsg), Gestalten der Kirchengeschichte, Band 10/1, Mainz 1985, 65.

15 Mark D Chapman, Theology within walls: Wilhelm Herrmann's religious reality, Neue Zeitschrift für Systematische Theologie und Religionsphilosophie 34/2 (1992), 69.

16 In die andersins uitstaaande biografiese artikel van Mahlmann, $a w, 1986,165$ oor Herrmann word hierdie teksvers foutiewelik as Jesaja 29:23 aangedui.

17 Wilhelm Herrmann, “Der geschichtliche Christus der Grund unseres Glaubens”, 1892, 323 in: Peter Fischer-Appelt, Wilhelm Herrmanns Schriften zur Grundlegung der Theologie, Teil I, München 1966.

18 Ten einde hierdie artikel vir lesers toeganglik te maak wat nie Duits kan lees nie, is gepoog om alle duitse aanhalings so getrou as moontlik in Afrikaans weer te gee. Terselfdertyd is taalmatig gepoog om iets van die trefkrag van die Duitse formulerings te behou alhoewel dit nie orals ewe moontlik of maklik is nie.

Herrmann, $a w, 1903,50$. 
20 Herrmann, $a w, 1903,148,164$.

21 Wilhelm Herrmann, "Der Evangelische Glaube und die Theologie Albrecht Ritschls", 1896, 13 in: Friedrich W Schmidt, Wilhelm Herrmann. Gesammelte Aufsätze, Tübingen 1923.

22 Herrmann, $a w, 1903,24$.

23 Vergelyk Herrmann, $a w, 1903,84$.

24 Vergelyk Herrmann, a w, 1903, 122, 165.

25 Herrmann, $a w, 1892,296$; Herrmann, $a w, 1903,133$.

26 Herrmann, $a w, 1903,1$.

$27 \quad$ Fischer-Appelt, $a w$.

28 Joachim Weinhardt, Wilhelm Herrmanns Stellung in der Ritschlschen Schule, Ongepubliseerde doktorale proefskrif, Tübingen 1993.

29 Vir 'n kort, samevattende uiteensetting van biografiese gegewens met betrekking tot Herrmann, kyk Mahlmann, $a w$.

30 Vergelyk Robert Voelkel, The communion of the christian with God. Described on the basis of Luther's statements. Philadelphia 1972, XVev; Berkhof, $a$ w, 149.

$31 \quad$ Veldsman, $a w, 1989,58 \mathrm{ev}$.

32 Veldsman, $a w, 41 \mathrm{ev;} \mathrm{Vergelyk} \mathrm{Brent} \mathrm{Sockness,} \mathrm{"The} \mathrm{Ideal} \mathrm{and} \mathrm{the} \mathrm{Historical}$ in the Christology of Wilhelm Herrmann: The Promise and the Perils of Revisionary Christology", Journal of Religion 72/3 (1992), 366ev.

33 Herrmann, $a w, 1903,54-5$.

34 Herrmann, $a w, 1903,4 \mathrm{ev}$.

35 Vergelyk Veldsman, $a w, 50 \mathrm{ev}$.

36 Vir 'n volledige uiteensetting en motivering van die voorgestelde fases in die denke van Herrmann, sien Veldsman, $a w, 50 \mathrm{ev}$, veral voetnota 67.

37 Vergelyk Veldsman, $a w, 72 \mathrm{ev}$.

38 Wilhelm Herrmann, "Die Lage und Aufgabe der evangelischen Dogmatik in der Gegenwart", 1907, 117ev in: Fischer-Appelt, $a w$. 
40 Herrmann, $a w, 1903,4$ gebruik - letterlik vertaal - die volgende mooi formulering hiervoor: "Die evangelie word selfs iets sinneloos deurdat ons op 'n sinnelose wyse mense met die evangelie belas en seermaak (quälen)”.

41 Wilhelm Herrmann, “Der Begriff der Offenbarung”, 1887, 127, 129; in: Fischer-Appelt, $a w, 1966$. Herrmann, $a w, 1903,66$.

42 Herrmann, $a w, 1892,321$; Vergelyk Herrmann, $a w, 1903,148 \mathrm{ev}$.

$43 \quad$ Herrmann, $a w, 1903,13$.

$44 \quad$ Herrmann, $a w, 1903,4$.

45 Onverbiddelik formuleer Herrmann, $a w, 1903,10$ : “Maar die idee van dogma as 'n eenvormige 'leerwet' staan in direkte teenspraak met die werk van die heilige Gees". Wat staan dan nie in teenspraak hiermee nie? Die geloofswerklikheid dat die heilige Gees mense tot individue maak (Der heilige Geist aber schafft Individuen des Glaubens). Vir Herrmann, a w, 1903, 10 klop dit dan ook met die getuieniskarakter van die Nuwe Testament wat nie na ons kom as onveranderlike, eenvormige en tydloos-geldende leersisteem nie. Tog en dit gee Herrmann dadelik toe - is daar altyd by die kerk die versugting om tot die formulering van leerstellighede oor te gaan. Dan moet egter goed ingedagte gehou word dat hierdie geformuleerde leerstellighede nooit ooit so in 'n gelowige geleef het nie (vgl Herrmann, $a w, 1903,11)$. Herrmann gaan selfs so ver om te sê dat leerstellighede wat geformuleer word ten einde gelowiges daarin te verenig, niks anders as "waardelose skedelspoke" (wertlose Hirngespinste) is.

46 Herrmann, $a w, 1903,65$.

47 In Herrmann, $a w, 1903,7$ se woorde: "Die nuwe dag van die evangeliese Christendom kan slegs in die harte van diegene deurbreek wie ingesien het dat opregte godsdienstige geloof geen ander wet kan verdra as die etiese wet van opregtheid en liefde nie".

48 Vergelyk Wilhelm Herrmann, Die Religion im Verhältnis zum Welterkennen und zur Sittlichkeit, Halle 1879, 207, 268.

49 In 'n breedvoerige uiteensetting (vgl Herrmann, $a w, 1903,16-46$ ) voer hy aan op watter punte hy saamstem en verskil met die opvattinge van die RoomsKatolieke Kerk met betrekking tot die betekenis van die mistiek in die Godservaring (veral 38-9; ook 162ev). Van die oortuiging dat geloof ten diepste en ten laaste 'n geheimsinnige en onoordraaglike karakter het, verskil Herrmann nie. Dat hierdie karakter egter slegs in 'n nie-meedeelbare, gevoelsmatige sin 
verstaan word, bestry Herrmann wel. Na sy oordeel (a) kan ons dan niks meer positief ("inhoudelik") van God en Christus sê behalwe dat hulle nie "wêreld" is nie, en (b) juis die geskiedenis waarbinne God Hom in Jesus Christus geopenbaar het (dit wil sê juis dit wat aan ons die positiewe inhoud kan gee), word nie ernstig geneem nie. Hierdie vorm van mistieke religiositeit eindig altyd in een of ander vorm van panteïsme aangesien die historiese as las gesien word waarvan die gelowige losgemaak moet word. Vir Herrmann kan dit nie, want ons verlosser het in die geskiedenis na ons gekom.

$50 \quad$ Herrmann, $a w, 1903,11$.

$51 \quad$ Herrmann, $a w, 1903,109$.

52 Herrmann, $a w, 1903,33$. Ter wille van duidelikheid, herhaal ek hier die belangrike, maar moeilike Duitse formulering van Herrmann: "Wir stellen sie also nicht als etwas Uerberliefertes dar, sondern als etwas gegenwärtig Wachsendes, als Glaubensgedanken”.

$53 \quad$ Herrmann, $a w, 1903,103$.

54 Vir die redes waarom en op watter spesifieke wyse Herrmann by Luther aansluit, vergelyk Herrmann, $a w, 1903,40-6 ; 112 \mathrm{ev.} \mathrm{Op} \mathrm{eiesoortige} \mathrm{wyse}$ formuleer Herrmann, $a w, 1903$, 45: "Luther se getuienis oor dit wat 'n Christen tot Christen maak, is 'n skat wat nog nie genoeg na waarde geskat is nie. Hierdie getuienis is nog veel meer van waarde as Luther se teologie, aangesien sy teologie iets van die verlede is”. Herrmann, $a w, 1903,128$ vind veral daarin by Luther aansluiting dat hy, net soos Herrmann, die vind van God (in Jesus) as die hoofsaak van sy teologiese worsteling gesien het. Dat Herrmann, $a w, 1903,129 \mathrm{ev}$ ook van Luther op baie punte verskil, stel hy ook baie duidelik.

$55 \quad$ Herrmann, $a w, 1903,49$.

$56 \quad$ Herrmann, $a w, 1903,51$.

$57 \quad$ Herrmann, $a w, 1903,51$.

58 Kernagtig stel Herrmann, $a w, 1903,52:$ "Die konkrete werklikheid waarin ons ons bevind moet die kos (Nahrung) van ons innerlike lewe word. Daarin dat ons dit beheer (beherzigen), kom God in ons hart”. Onder konkrete werklikheid verstaan Herrmann menslike samesyn en die geskiedenis, maar nie die natuur nie. Laasgenoemde sien hy alleen maar as die middel tot die doel van menslike bestaan (Mittel für die Existenz der Gesellschaft).

59 Herrmann gee hierin vir Lessing gelyk dat religieuse oortuiginge nie op historiese oordele kan berus nie (vgl Veldsman, $a w, 72)$. 